\title{
PENDUGAAN UMUR SIMPAN KUKIS MOCAF DENGAN METODE AKSELERASI BERDASARKAN KADAR AIR KRITIS
}

\section{SHELF LIFE STUDY OF MOCAF COOKIES USING A CRITICAL MOISTURE CONTENT APPROACH}

\author{
Woro Setiaboma, Dita Kristanti, Nok Afifah \\ Pusat Penelitian Teknologi Tepat Guna, Lembaga Ilmu Pengetahuan Indonesia, \\ Jalan Aipda K.S. Tubun No 5 Subang, Jawa Barat, Indonesia 4123 \\ Email : wrboma@gmail.com/dita.kristanti@gmail.com
}

Diterima : 05-02-2020

Direvisi :09-06-2019

Disetujui : 19-07-2020

\begin{abstract}
ABSTRAK
Umur simpan menentukan kualitas produk kukis mocaf, ditandai dengan kekerasan atau kerenyahan yang masih bisa diterima oleh konsumen. Kurva isoterm sorpsi air dapat digunakan untuk menentukan umur simpan berdasarkan kadar air kritis. Tujuan penelitian ini yaitu mengetahui karakteristik kukis mocaf dan memprediksi umur simpannya berdasarkan permodelan matematika. Pendugaan umur simpan diawali dengan analisa kadar air awal $\left(\mathrm{M}_{0}\right)$ kemudian dilanjutkan dengan penentuan kadar air kritis $\left(M_{c}\right)$ berdasarkan analisa sensoris serta kadar air kukis mocaf yang disimpan tanpa kemasan di ruang dengan suhu $30^{\circ} \mathrm{C}$ dan $\mathrm{RH} 75-80 \%$ pada periode waktu 0-7 jam. Penentuan kadar air keseimbangan $\left(\mathrm{M}_{\mathrm{e}}\right)$ dilakukan dengan mengukur kadar air kukis pada $\mathrm{RH}$ 6,95-83,62\% yang dikondisikan menggunakan larutan garam jenuh. Permodelan isoterm sorpsi air (ISA) dibuat berdasarkan hubungan antara kadar air kesetimbangan dengan aktivitas air $\left(\mathrm{a}_{\mathrm{w}}\right)$. Pengujian ketepatan model ISA dilakukan dengan menghitung Mean Realtive Determination (MRD). Model persamaan dengan nilai MRD $\leq 10$ digunakan untuk penentuan umur simpan kukis. Hasil penelitian menunjukkan bahwa kukis mocaf memiliki kadar air 5,04 \%(bk), kadar abu 1,39\%(bk), kadar protein 3,29 \%(bk), kadar lemak 22,01\%(bk), karbohidrat by difference 68,28\%(bk) dan energi sebesar $484 \mathrm{kal} / 100 \mathrm{~g}$. Permodelan yang tepat untuk pendugaan umur simpan kukis mocaf adalah permodelan GuggenheimAnderson-de Boer (GAB) dengan bentuk kurva ISA sigmoid (tipe II) dan nilai MRD sebesar 8,44\%. Pendugaan umur simpan kukis mocaf paling baik pada kondisi suhu $30^{\circ} \mathrm{C}$ dan $\mathrm{RH} 80 \%$ menggunakan kemasan aluminium dengan umur simpan selama 16,7 bulan.
\end{abstract}

Kata kunci: isoterm sorpsi air, kukis mocaf, umur simpan

\section{ABSTRACT}

The shelf life of mocaf cookies determinesthe quality of the product that could be accepted of consumers based on hardness and crispiness. Moisture sorption isotherm curve could be used to determine the shelf life according to critical moisturecontent. The aims of this study were to obtain the characteristic of mocaf cookies and to predict the shelf life based on mathematical modeling. Estimating the shelf life was begun with an analysis of initial moisture content $\left(M_{0}\right)$ andthandetermination of critical moisture content $\left(M_{c}\right)$ based on sensory analysis and moisturecontent of the cookies that stored without packaging at $30^{\circ} \mathrm{C}$ and $\mathrm{RH} 75-80 \%$ in a period of 0-7 hours. Determination of equilibrium moisture content $\left(M_{e}\right)$ was done by measuring the moisture content of the cookies in $\mathrm{RH} 6.69 \%-83.62 \%$ using various saturated salt solutions. Moisture sorption isotherm modeling was made based on the relationship of equilibrium moisture content $\left(M_{e}\right)$ and water activity $\left(a_{w}\right)$. Accuracy testing of the model was done by calculating mean relative determination (MRD). The model with a value of MRD $\leq 10$ was used for determining the shelf life. The results show that mocaf cookies contain $5.04 \%(d b)$ of moisture content, $1.39 \%(d b)$ of ash, $3.29 \%(d b)$ of protein, $22.01 \%(\mathrm{db})$ of fat, $68.28 \%(\mathrm{db})$ of carbohydrate by difference, and $484 \mathrm{cal} / 100 \mathrm{~g}$ of energy. The appropriate modeling for estimating the shelf life of mocaf cookies was the Guggenheim Aderson-e 
Boer (GAB) model with a sigmoid curve type II and $8.44 \%$ of the MRD level. The best shelf life estimation of mocaf cookies at $30^{\circ} \mathrm{C}$ and $\mathrm{RH} 80 \%$ was using aluminium foil packagingfor 16.7 months.

Keywords: sorption isotherm, mocaf cookies, shelflife

\section{PENDAHULUAN}

ukis merupakan produk makanan ringan sejenis biskuit dengan tekstur renyah. Bahan baku utama pembuatan kukis di Indonesia adalah terigu. Indonesia merupakan negara yang tidak dapat memproduksi terigusehingga dilakukan imporuntuk mencukupi kebutuhan tersebut. Total impor terigu di Indonesia selama 2018 sebanyak 61.718 ton (Pusat Data dan Sistem Informasi Pertanian, 2015). Menurut Aptindo (2003) dalam (Ningtyas et al., 2012), konsumsi terigu untuk biskuit sebesar $15 \%$ dari total konsumsi nasional. Pengurangan impor terigu dapat dilakukan melalui penggantian terigudengan komoditi lokal, salah satunya yaitu mocaf. Mocaf merupakan tepung yang terbuat dari modifikasi singkong dengan cara fermentasi menggunakan bakteri asam laktat. Modifikasi akan menyebabkan perubahan karakteristik pada mocaf seperti peningkatan viskositas, kemampuan membentuk gel (gelasi), daya rehidrasi dan kemudahan melarut (Assalam et al., 2019). Perbedaan utama mocaf dengan terigu adalah adanya protein gluten pada terigu.

Kukis mocaf merupakan produk kukis dengan bahan baku utama berupamocaf. Penelitian tentang kukis mocaf terutama untuk kukis bebas gluten telah banyak dilakukan. Beberapa penelitian kukis mocaf telah dilakukan antara lain adalah kukis dari mocaf dan tepung bekatul dengan penambahan margarin (Mulyani et al., 2015); dan kukis mocaf dengan tepung beras pecah kulit dan sari kurma (Alvionita et al., 2017). Permasalahan yang muncul setelah kukis dibuat yaitu umur simpan atau masa konsumsi kukis. Umur simpan ditentukan dari rentang waktu produk dapat diterima oleh konsumen karena perubahan mutu produk. Kerusakan produk pangan kering banyak yang disebabkan penyerapan air dari produk selama penyimpanan. Penurunan kualitas kukis dapat diamati dari penurunan kekerasan atau kerenyahan (Wijaya et al., 2014). Stabilitas kukis ditentukan oleh kadar airdan aktivitas air $\left(a_{w}\right)$. Kurva isotermis dapat digunakan untuk menentukan umur simpan bahan pangan berdasarkan batas kritis yang harus dicapai(Alfiah et al., 2017). Kurva isoterm sorpsi air dengan model matematika digambarkan dalam bentuk hubungan antara kadar air dan aktivitas air.

Beberapa model matematika kurva isoterm sorpsi yang digunakan yaitu persamaan model Guggenheim-Anderson-de Boer (GAB), Brunauer-Emmett-Teller (BET), Oswin, Smith, Hasley, Henderson, Caurie, dan Chen-Cleyton. Model GAB merupakan model matematika yang memiliki ketepatan tinggi pada kisaran $a_{w}$ yang luas pada bahan pangan (Wijaya et al., 2014). Masing-masing model memiliki kesesuaian pendekatan absorbsi atau desopsi dan tidak seluruh model dapat diterapakan pada bahan pangan. Model GAB dan BET merupakan model yang paling sering digunakan dalam prediksi ISA (Aini el al., 2014). Tujuan penelitian ini adalah mengetahui karakteristik kukis mocaf dan memprediksi umur simpan kukis mocaf berdasarkan permodelan matematika yang diuji dengan Mean Relative Deviation (MRD).

\section{METODE PENELITIAN Bahan}

Bahan penelitian yang digunakan adalah kukis mocafyang diperoleh dari salah satu UKM di Kota Subang, Jawa Barat. Jenis kemasan yang digunakan adalah kemasan metalizer plastic,oriented polypropylene/OPP, polietilen/PE dan aluminium foil. Komposisi bahan pembuatan kukis mocaf ditampilkan pada Tabel 1. Pembuatan kukis sesuai dengan Kristanti et al. (2020). 
Tabel 1. Komposisi bahan pembuatan kukis mocaf

\begin{tabular}{lc}
\multicolumn{1}{c}{ Bahan } & Jumlah (\%) \\
\hline Mocaf & 39,84 \\
Telur & 23,90 \\
Margarin & 17,93 \\
Gula aren & 11,95 \\
Gula halus & 3,98 \\
Tapioka & 1,99 \\
Baking powder & 0,40 \\
Garam & 0,20 \\
\hline
\end{tabular}

\section{Analisa Produk}

Analisa proksimat kukis mocaf meliputi: analisa kadar air; kadar abu dengan metode gravimetri; kadar protein dengan metode Kjeldahl; kadar lemak dengan metode Soxhlet, kadar karbohidrat ditentukan dengan metode by difference; dan kadar asam lemak bebas sebagai Oleat (AOAC, 1995). Analisa timbal (Pb) dilakukan menggunakan Atomic Absorption Spectoscopy (AAS). Analisa cemaran mikroba meliputi Angka Lempeng Total (ALT) pada suhu $30^{\circ} \mathrm{C}$ selama 72 jam (Badan Standardisasi Nasional, 2012), Escherichia coli(Badan Standardisasi Nasional, 2011), Salmonella sp. (ISO, 2002), Kapang, dan Khamir (Badan Standardisasi Nasional, 2011). Kerenyahan dan daya patah diukur menggunakan TA.XT Plus texture analyzer (Stable Micro Systems, Great Britain) dengan probe 3-point bend, model tes compression, kecepatan tes 3,00 mm/detik dan target force $50 \mathrm{~g}$ (Öksüz dan Karakaş, 2016). Pengujian organoleptik menggunakan uji hedonik terhadap rasa, tekstur, warna, aroma, dan penerimaan keseluruhan (Soekarto dan Hubeis, 1992) yang dilakukan oleh 30 panelis tidak terlatih di Pusat Penelitian Teknologi Tepat Guna (P2 TTG) LIPI.Skala nilai terdiri dari 1: sangat tidak suka, 2: tidak suka, 3: agak suka, 4: suka, dan 5: sangat suka.

\section{Pendugaan Umur Simpan Produk}

Pendugaan umur simpan kukis mocaf dilakukan dengan metode akselerasi berdasarkan pendekatan kadar air kritis. Tahapan pendugaan umur simpan kukis mocaf adalah sebagai berikut:

Pengukuran kadar air awal $\left(\mathbf{M}_{\mathbf{0}}\right)$ dan berat awal produk. Kadar air kukis mocaf sebelum disimpan diukur dengan metode gravimetri (AOAC, 1995) dan dinyatakan sebagai $\mathrm{g}$ $\mathrm{H}_{2} \mathrm{O} / \mathrm{g}$ padatan. Berat awal kukis mocaf dalam satu kemasan ditimbang kemudian dikoreksi sesuai $\mathrm{M}_{\mathrm{o}}$. Berat awal produk dinyatakan sebagai g padatan per kemasan.

Penentuan kadar air kritis $\left(\mathbf{M}_{\mathbf{c}}\right)$. Penentuan $\mathbf{M}_{\mathrm{c}}$ kukis mocaf dilakukan dengan pengujian sensoris terhadap kukis yang sebelumnya telah disimpan tanpa kemasan pada suhu kamar $\left(30^{\circ} \mathrm{C}\right)$ (Kusnandar et al., 2010). Pengujian sensoris dilakukan oleh 30 panelis tidak terlatih dengan skala penilaian skor 1 (tidak renyah) sampai skor 7 (sangat tidak renyah). Pada setiap periode pengujian sensoris juga dilakukan analisa kadar air dengan metode gravimetri (AOAC, 1995) dan kerenyahan (Öksüz dan Karakaş, 2016). Kadar air kritis ditentukan pada saat uji sensoris bernilai 3 (agak tidak renyah) yang menandakan kerenyahan kritis pada kukis.

Penentuan kadar air kesetimbangan $\left(\mathbf{M}_{\mathbf{e}}\right)$. Penentuan $M_{e}$ kukis mocaf dilakukan dengan pembuatan kurva isoterm sorpsi air kukis dengan menggunakan larutan garam jenuh $\mathrm{NaOH}$, $\mathrm{MgCl}_{2}, \mathrm{KI}, \mathrm{NaCl}$, dan $\mathrm{KCl}$ (Merck Millipore, Jerman). Larutan garam jenuh tersebut digunakan untuk menciptakan kondisi lingkungan dengan RH berkisar antara 6,95-83,62\% atau aktivitas air $\left(\mathrm{a}_{\mathrm{w}}\right)$ berkisar antara 0,07-0,84 (Tabel 2). 
Tabel 2. Kelembaban relatif $(\mathrm{RH})$ dan aktivitas air $\left(a_{w}\right)$ larutan garam pada suhu $30^{\circ} \mathrm{C}$

\begin{tabular}{|c|c|c|}
\hline $\begin{array}{l}\text { Larutan } \\
\text { garam }\end{array}$ & $\begin{array}{c}\text { Kelembaban relatif/RH } \\
(\%)\end{array}$ & $\begin{array}{l}\text { Aktivitas air } \\
\left(a_{w}\right)\end{array}$ \\
\hline $\mathrm{NaOH}$ & 6,95 & 0,069 \\
\hline $\mathrm{MgCl}_{2}$ & 32,44 & 0,324 \\
\hline KI & 67,89 & 0,679 \\
\hline $\mathrm{NaCl}$ & 75,09 & 0,751 \\
\hline $\mathrm{KCl}$ & 83,62 & 0,836 \\
\hline
\end{tabular}

Kukis mocaf yang telah dihaluskan ditimbang sekitar $2 \mathrm{~g}$ dan diletakkan pada cawan konstan. Selanjutnya diletakkan pada desikator yang berisi larutan garam-garam jenuh secara triplo. Desikator disimpan pada suhu kamar $\left(30^{\circ} \mathrm{C}\right)$. Penimbangan bobot sampel dilakukan setiap hari secara periodik hingga mencapai kadar air kesetimbangan yang ditandai dengan selisih 3 penimbangan berturut-turut $\leq 2 \mathrm{mg} / \mathrm{g}$ ( $\mathrm{RH}$ di bawah 90\%). Setelah mencapai kadar air kesetimbangan, sampel kemudian dianalisa kadar airnya dengan metode gravimetri (AOAC, 1995) sehingga diperoleh $\mathrm{M}_{\mathrm{e}}$ yang dinyatakan sebagai $\mathrm{g} \mathrm{H}_{2} \mathrm{O} / \mathrm{g}$ padatan (Kusnandar et al., 2010).

Pemodelan isoterm sorpsi air. Data hubungan antara $M_{e}$ dan $a_{w}$ diuji menggunakan model persamaan Guggenheim-Anderson-de Boer (GAB), Brunauer-Emmett-Teller (BET), Oswin, Smith, Hasley, Henderson, Caurie, dan Chen-Cleyton. Pengujian ketepatan model dilakukan dengan menghitung Mean Relative Determination (MRD) menggunakan persamaan 1.

$M R D=\frac{100}{n} \sum_{i=1}^{n}\left|\frac{\text { kadar air percobaan }- \text { kadar air perhitungan }}{\text { kadar air percobaan }}\right| \ldots \ldots$ (1)

Nilai MRD $<5$ menyatakan model isoterm sorpsi air sangat tepat menggambarkan kondisi sebenarnya, nilai $5<M R D<10$ menyatakan model isoterm sorpsi air agak tepat menggambarkan kondisi sebenarnya, dan nilai MRD > 10 menyatakan model isoterm tidak tepat menggambarkan kondisi sebenarnya (Kusnandar et al., 2010). Model yang terpilih digunakan untuk menentukan nilai slope kurva isoterm sorpsi air yang digunakan untuk penentuan umur simpan kukis. Pendugaan umur simpan kukis mocaf dilakukan dengan perhitungan menggunakan persamaan 2 .

umur simpan $=\frac{\ln \frac{(M e-M o)}{(M e-M c)}}{\frac{k}{x}\left(\frac{A}{W_{s}}\right) \frac{P_{o}}{b}} \ldots$ (2)

dimana, $\quad \mathrm{M}_{\mathrm{e}}=$ kadar air kesetimbangan produk ( $\mathrm{g} \mathrm{H}_{2} \mathrm{O} / \mathrm{g}$ padatan)

$\mathrm{M}_{\mathrm{o}}=$ kadar air awal produk ( $\mathrm{g} \mathrm{H}_{2} \mathrm{O} / \mathrm{g}$ padatan)

$\mathrm{b}=$ kemiringan (slope) kurva isoterm sorpsi air

$\mathrm{M}_{\mathrm{c}}=$ kadar air kritis $\left(\mathrm{g} \mathrm{H}_{2} \mathrm{O} / \mathrm{g}\right.$ padatan)

$\mathrm{k} / \mathrm{x}=$ konstanta permeabilitas uap air kemasan $\left(\mathrm{g} / \mathrm{m}^{2}\right.$.hari.mmHg)

$A=$ luas permukaan kemasan $\left(\mathrm{m}^{2}\right)$

Ws = berat kering produk dalam kemasan (g padatan)

Po $=$ tekanan uap jenuh $(\mathrm{mmHg})$ 
Karakteristik mutu awal kukis mocaf yang diamati pada penelitian ini antara lain adalah kadar air, abu, protein, lemak, karbohidrat, energi, asam lemak (dihitung sebagai oleat), timbal, cemaran mikroba (ALT, E. coli, Salmonella sp, kapang, dan khamir), kerenyahan dan pengujian sensoris. Karakteristik mutu awal kukis mocaf ditampilkan pada Tabel 3.

Tabel 3.Karakteristik mutu awal kukis mocaf

\begin{tabular}{lcc}
\hline Parameter & Hasil pengujian & Standar mutu kukis 2973:2011 \\
\hline Air (\%bk) & $5,04 \pm 0,03$ & Maks. 5 \\
Abu (\%bk) & $1,39 \pm 0,00$ & - \\
Protein (\%bk) & $3,29 \pm 0,01$ & Min. 4,5 \\
Lemak (\%bk) & $22,01 \pm 0,01$ & - \\
Karbohidrat (\%bk) & $68,28 \pm 0,04$ & - \\
Energi (kal/100 g) & 484 & - \\
Asam lemak sebagai oleat (\%) & $0,16 \pm 0,00$ & Maks. 1,0 \\
Timbal/Pb (mg/kg) & $<0,23 \pm 0,01$ & Maks. 0,5 \\
ALT (koloni/g) & $1,05 \times 10^{5}$ & Maks. $1 \times 10^{4}$ \\
E. coli (APM/g) & $<3$ & $<3$ \\
Salmonella sp.(koloni/25 g) & Negatif & Negatif \\
Kapang (koloni/g) & $<7,5$ & Maks $1 \times 10^{2}$ \\
Khamir (koloni/g) & $<10$ & Maks 2x10 \\
Warna & $2,63 \pm 0,89$ & \\
Aroma & $3,84 \pm 0,96$ & \\
Tekstur & $3,84 \pm 0,90$ & \\
Rasa & $3,84 \pm 0,83$ & \\
Penerimaan keseluruhan & $3,89 \pm 0,88$ & \\
\hline
\end{tabular}

Hasil analisa menunjukkan bahwa kadar air, kadar protein, dan ALT tidak sesuai dengan standar mutu kukis berdasarkan SNI 2973:2011, sedangkan kadar asam lemak bebas, timbal, E. coli, dan Salmonella sp. sudah sesuai (Badan Standardisasi Nasional, 2011). Penelitian Alvionita et al. (2017) menyatakan bahwa kukis mocaf dengan bekatul memiliki kandar protein yang lebih rendah dari standar SNI kukis. Kukis mocaf memiliki kadar protein lebih kecil dari kukis terigu karena kandungan protein pada mocaf lebih rendah dari terigu. Terigu memiliki protein berupa gluten yang dapat menambah kandungan protein pada kukis. Secara umum, hasil pengamatan organoleptik menunjukan bahwa kukis mocaf diterima berdasarkan parameter aroma, tekstur, rasa, dan penerimaan secara keseluruhan yang ditunjukan dari hasil nilai yang lebih dari 3 (agak suka).

\section{Kadar air awal $\left(\mathbf{M}_{\mathrm{i}}\right)$ dan Kadar air kritis $\left(\mathbf{M}_{\mathrm{c}}\right)$}

Kadar air awal kukis mocaf adalah $0,0516 \mathrm{~g} \mathrm{H}_{2} \mathrm{O} / \mathrm{g}$ solid sehingga berat padatan per kemasan sebesar 95,09 g. Kadar air kritis ditentukan berdasarkan penurunan tekstur kerenyahan kukis mocaf hasil pengujian sensoris pada berberapa periodik waktu (0-7 jam). Tabel 4 merupakan data perubahan kadar air, nilai kerenyahan, dan skor kesukaan panelis terhadap kukis mocaf.

Tabel4. Perubahan kadar air, nilai kerenyahan, dan skor kerenyahan kukis mocaf

\begin{tabular}{lccc}
\hline Waktu & $\begin{array}{c}\text { Kadar air } \\
\left(\mathrm{g} \mathrm{H}_{2} \mathrm{O} / \mathrm{g} \text { padatan }\right)\end{array}$ & $\begin{array}{c}\text { Kerenyahan } \\
(\mathrm{gF})\end{array}$ & Skor kerenyahan \\
\hline 0 & $0,050 \pm 0,0003$ & $9140,72 \pm 37,00$ & $5,10 \pm 1,52$ \\
1 & $0,053 \pm 0,0002$ & $6836,60 \pm 204,19$ & $4,30 \pm 1,63$ \\
3 & $0,054 \pm 0,0004$ & $4967,66 \pm 62,83$ & $4,20 \pm 1,47$
\end{tabular}




\begin{tabular}{llcl}
5 & $0,064 \pm 0,0001$ & $4530,17 \pm 181,11$ & $3,35 \pm 1,14$ \\
7 & $0,072 \pm 0,0002$ & $4444,65 \pm 65.40$ & $2,55 \pm 0,89$ \\
\hline
\end{tabular}

Kadar air kritis diperoleh dari persamaan garis yang dibentuk dari grafik hubungan antara kadar air dan skor kerenyahan panelis, yaitu kadar air dimana skor kerenyahan bernilai 3 dari interval waktu yang ditentukan. Grafik hubungan antara kadar air dan skor kerenyahan panelis ditampilkan pada Gambar 1 . Persamaan yang diperoleh adalahy = $0,0085 x+0,0921\left(R^{2}=0,932\right)$. Berdasarkan persamaan tersebut, nilai kadar air kritis kukis mocaf pada penelitian ini adalah 0,067.

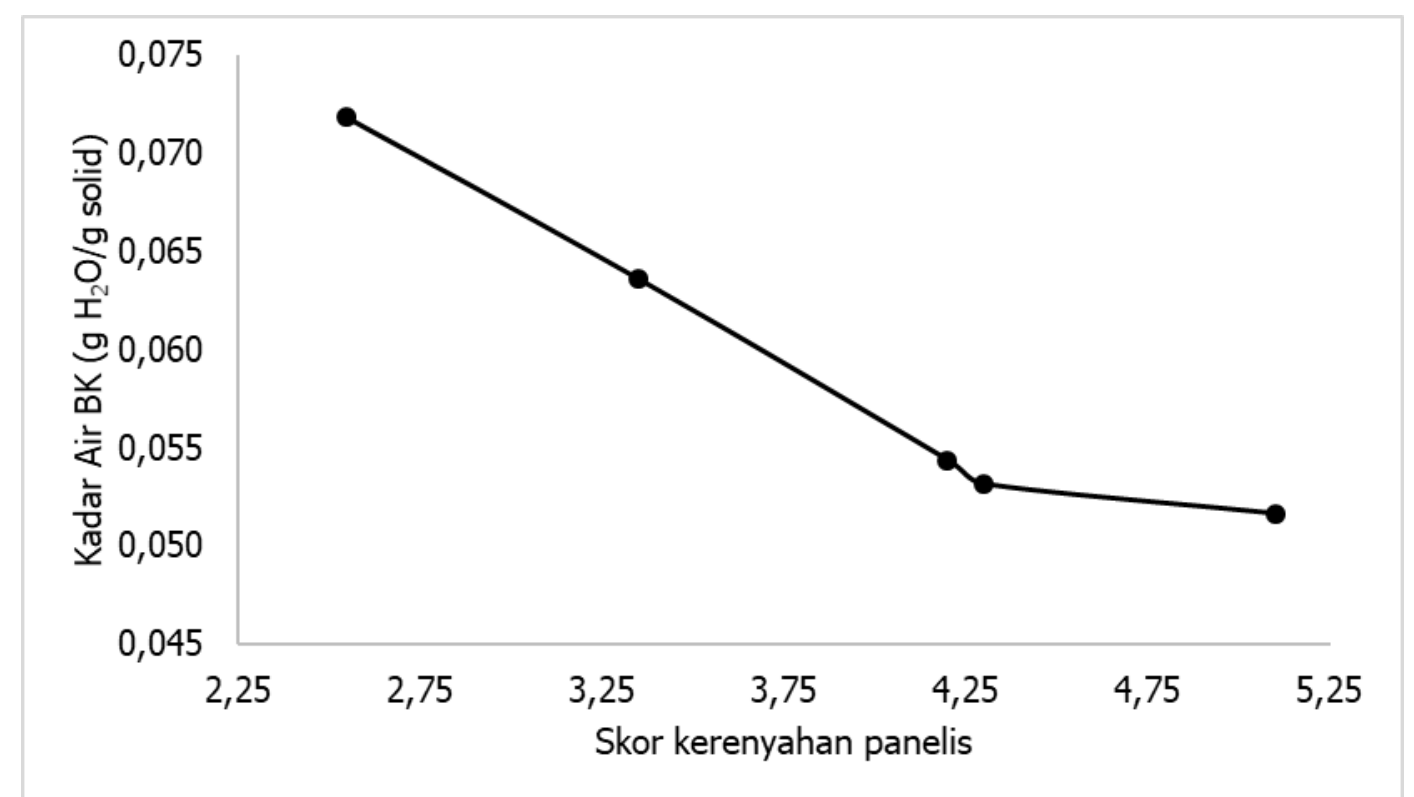

Gambar 1.Grafik hubungan antara kadar air dan skor kerenyahan panelis

\section{Kadar air keseteimbangan $\left(M_{e}\right)$ dan Kurva isoterm sorpsi air pada kukis}

Kadar air kesetimbangan $\left(\mathrm{M}_{\mathrm{e}}\right)$ pada kukis mocaf tercapai setelah disimpan 6-10 hari pada berbagai garam jenuh. Kurva isoterm sorpsi air merupakan kurva yang dibentuk dari kadar air kesetimbangan hasil percobaan dengan nilai $a_{w}$ lingkungan penyimpanan (garam jenuh). Data hubungan antara $M_{e}$ dan $a_{w}$ selanjutnya diuji menggunakan model persamaan Guggenheim-Anderson-de Boer (GAB), Brunauer-Emmett-Teller (BET), Oswin, Smith, Hasley, Henderson, Caurie, dan Chen-Cleyton untuk memperoleh nilai MRD. Persamaan kurva isoterm sorpsi air kukis mocaf dan nilai MRD ditampilkan pada Tabel 5.

Tabel5. Persamaan kurva isoterm sorpsi air kukis mocaf dan nilai MRD

\begin{tabular}{llc}
\hline $\begin{array}{l}\text { Model } \\
\text { persamaan }\end{array}$ & \multicolumn{1}{c}{ Persamaan } & \%MRD \\
\hline GAB & $M_{e}=0,6690 a_{w} /\left(1-1,0134 a_{w}\right)(1+$ & 8,44 \\
& $\left.22,219 a_{w}\right)$ & 59,68 \\
BET & $M_{e}=0,4443 a_{w} /\left(1-a_{w}\right)\left(1+64,2332 a_{w}\right)$ & 15,37 \\
Oswin & $\ln M_{e}=-2,6446+0,5442 \ln \left(a_{w} / 1-a_{w}\right)$ & 32,84 \\
Smith & $M_{e}=-0,0030-0,1067 \ln \left(1-a_{w}\right)$ & 10,84 \\
Hasley & $\log \left(\ln 1 / a_{w}\right)=-1,5487-1,1424 \log M_{e}$ & 23,85 \\
Henderson & $\log \left(\ln 1 /\left(1-a_{w}\right)\right)=1,3062+1,3361 \log M_{e}$ & 82,77 \\
Caurie & $\ln M_{e}=-4,1539-2,8667 a_{w}$ & 74,25 \\
Chen-Cleyton & $\ln \left(\ln 1 / a_{w}\right)=0,6073-11,791 M_{e}$ & \multicolumn{1}{c}{} \\
\hline
\end{tabular}


Model GAB merupakan model persamaan yang terpilih untuk penentuan umur simpan kukis mocaf karena memiliki nilai MRD terkecil diantara model yang lainnya. Model GAB memiliki rentang $a_{w}$ 0,9 sehingga model ini tepat untuk mendeskripsikan data-data isoterm sorpsi air. Semakin rendah nilai \% MDR menggambarkan keadaan sebenarnya dengan sangat tepat (Kusnandar et al., 2010). Penelitian Alfiah et al.(2017) menyatakan bahwa permodelan GAB menunjukan nilai MRD yang paling kecil $(<5)$ dibandingkan permodelan lain pada produk tepung fermentasi angkak.

Perbandingan antara kurva hubungan antara kadar air kesetimbangan hasil percobaan dan perhitungan $G A B$ dengan nilai $a_{w}$ lingkungan penyimpanan ditampilkan pada Gambar 2 . Kurva ISA pada Gambar 2 menunjukan bentuk $S$ atau sigmoid, sehingga kurva kukis mocaf mendekati tipe II. Bentuk kurva tipe II banyak dijumpai pada produk pangan terutama produk kering selain itu bentuk kurva ini terjadi karena kombinasi efek koligatif, kapiler dan interaksi air permukaan (Wijaya et al., 2014; Alfiah et al., 2017). Berdasarkan Gambar 2 dapat diketahui bahwa kurva hasil percobaan dan model GAB saling berhimpitan, hal ini menunjukan fenomena sorpsi kukis mocaf terjadi secara tepat sesuai keadaan sebenarnya.

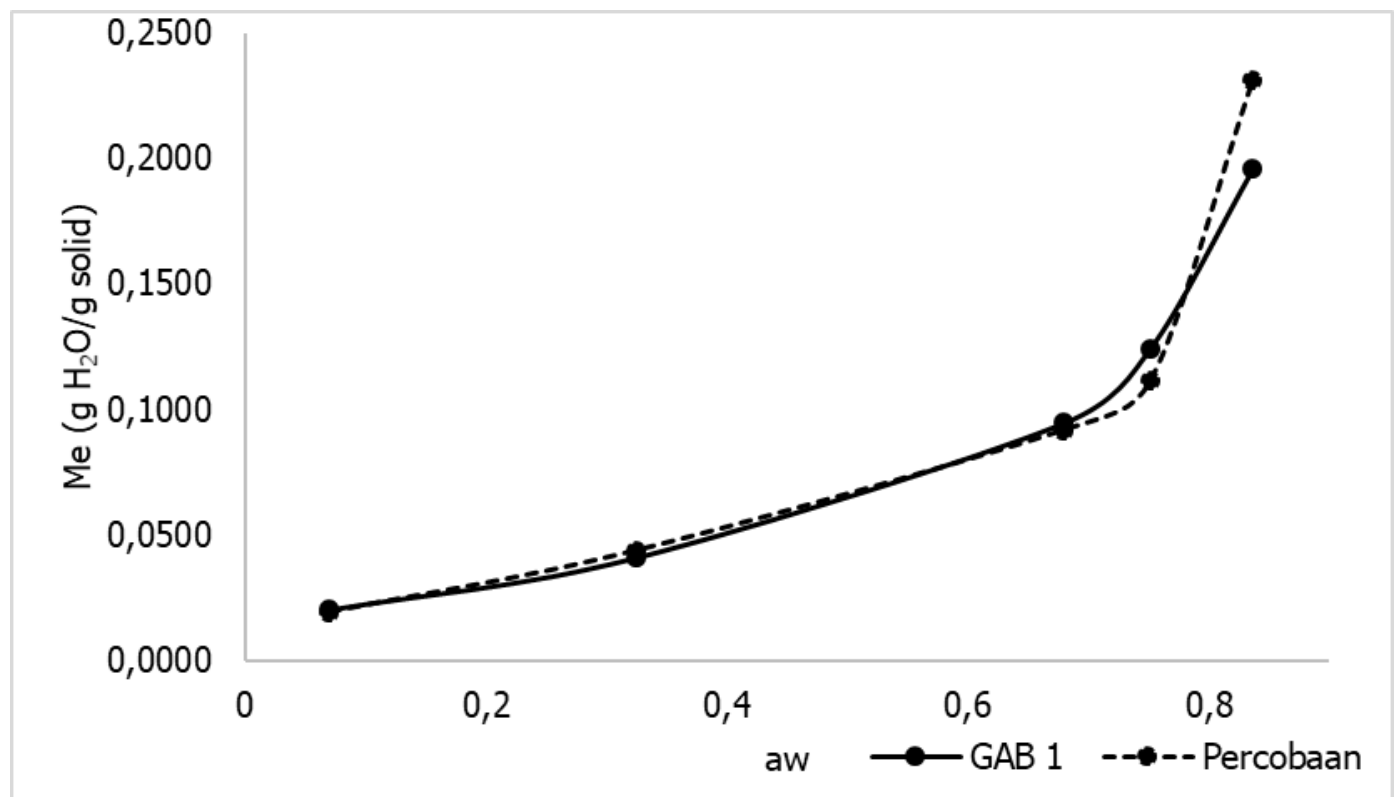

Gambar 2.Perbandingan kurva isoterm sorpsi air (ISA) hasil percobaan dan perhitungan GAB

Perhitungan kadar air kesetimbangan $\left(\mathrm{M}_{\mathrm{e}}\right)$ dihitung pada $\mathrm{a}_{\mathrm{w}}$ penyimpanan $75 \%, 80 \%$, dan $85 \%$ berdasarkan model persamaan terpilih, yaitu GAB yang ditampilkan pada Tabel 5 . Data kadar air kesetimbangan pada $\mathrm{a}_{\mathrm{w}}$ penyimpanan ditampilkan pada Tabel 6.

Tabel6. Kadar air kesetimbangan pada berbagai $\mathrm{a}_{\mathrm{w}}$ penyimpanan berdasarkan model persamaan kurva isoterm terpilih

\begin{tabular}{cc}
\hline $\begin{array}{c}\mathrm{a}_{\mathrm{w}} \text { penyimpanan } \\
(\%)\end{array}$ & $\begin{array}{c}\text { Kadar air kesetimbangan } \\
\left(\mathrm{g} \mathrm{H}_{2} \mathrm{O} / \mathrm{g} \text { solid }\right)\end{array}$ \\
\hline 75 & 0,1235 \\
80 & 0,1571 \\
85 & 0,2151 \\
\hline
\end{tabular}




\section{Umur Simpan Produk}

Umur simpan produk ditentukan pada tiga kondisi $\mathrm{a}_{\mathrm{w}}$ penyimpanan $(75 \%$, 80\%, dan $85 \%$ ). Dalam penentuan umur simpan produk digunakan parameter permeabilitas uap air kemasan, luas kemasan, berat solid produk per kemasan, dan tekanan uap air murni pada suhu ruang penyimpanan. Pada penelitian ini tidak dilakukan pengukuran permeabilitas uap air kemasan sehingga data yang digunakan berasal hasil penelitian yang sudah ada. Permeabilitas kemasan yang digunakan antara lain 0,0180 g H $2 \mathrm{O} /$ hari $/ \mathrm{m}^{2}$ (metalizerd plastic), $0,0740 \mathrm{~g} \mathrm{H}_{2} \mathrm{O} /$ hari/m² (oriented polypropylene/OPP), 0,050 g H $\mathrm{m}_{2} \mathrm{O} /$ hari $/ \mathrm{m}^{2}$ (polietilen), dan $0,004 \mathrm{~g} \mathrm{H}_{2} \mathrm{O} /$ hari/m $\mathrm{m}^{2}$ (aluminium foil)(Pertiwi dan Ginting, 2017; Pratiwi, 2017). Luas kemasan yang digunakan sebesar 0,0450 $\mathrm{m}^{2}$ dengan ukuran $(12,5 \times 18 \times 2)$, berat produk perkemasan sebesar $95,09 \mathrm{~g}$ solid, dan tekanan uap jenuh pada suhu $30^{\circ} \mathrm{C}$ sebesar 31,82 $\mathrm{mmHg}$. Pendugaan umur simpan kukis mocaf dilakukan dengan penghitungan menggunakan persamaan 2. Umur simpan kukis mocaf pada berbagai kondisi penyimpanan dan jenis kemasan ditampilkan pada Tabel 7.

Tabel 7. Umur simpan kukis mocaf pada berbagai kondisi penyimpanan dan jenis kemasan Umur simpan

\begin{tabular}{lcccccc}
\cline { 2 - 7 } \multicolumn{1}{c}{ Jenis kemasan } & \multicolumn{2}{c}{$75 \%$} & \multicolumn{2}{c}{$80 \%$} & \multicolumn{2}{c}{$85 \%$} \\
\cline { 2 - 7 } & Hari & Bulan & Hari & Bulan & Hari & Bulan \\
\hline Metalizerd plastic & 170 & 5,7 & 111 & 3,7 & 70 & 2,3 \\
Oriented Polypropylene/OPP & 41 & 1,4 & 27 & 0,9 & 17 & 0,6 \\
Polietilen/PE & 61 & 2 & 40 & 1,3 & 25 & 0,8 \\
Aluminium foil & 765 & 25,5 & 501 & 16,7 & 315 & 10,5 \\
\hline
\end{tabular}

Berdasarkan Tabel 7, nilai RH yang semakin tinggi pada berbagai kemasan menunjukan umur simpan yang semakin pendek. Berdasarkan jenis kemasan, kemasan aluminium foil memiliki umur simpan yang lebih lama dibandingkan kemasan metalizerd plastic, OPP dan PE. Hal ini disebabkan permeabilitas aluminium foil yang kecil. Penentuan umur simpan atau kadaluarsadari kukis mocaf yang tertera pada kemasan adalah 3 bulan sebelum waktu umur simpan.

\section{KESIMPULAN}

Kukis mocaf memiliki kadar air 5,04\%(bk), kadar abu 1.39\%(bk), kadar protein 3,29\%(bk), kadar lemak 22,01\%(bk), karbohidrat by difference 68,28\%(bk), dan energi sebesar $484 \mathrm{kal} / 100 \mathrm{~g}$. Kukis mocaf memiliki tipe kurva ISA sigmoid (tipe II) dengan persamaan Guggenheim-Anderson-de Boer (GAB) yang bisa memprediski kadar air kesetimbangan dengan baik. Kadar air kritis kukis mocaf yaitu 0,067. Prediksi umur simpan kukis mocaf menggunakan kemasan aluminium foil pada RH $80 \%$ yaitu 16,7 bulan, namun dalam informasi umur simpan untuk kadaluarsa pada kemasan yaitu 13,7 bulan.

\section{UCAPAN TERIMA KASIH}

Penulis mengucapkan terima kasih kepada Program IPTEK untuk Daerah (IPTEKDA) 2019 LIPI pada pendanaan penelitian ini. Ucapan terima kasih juga disampaikan kepada P2 TTG LIPI atas penyediaan fasilitas untuk penelitian ini. 


\section{DAFTAR PUSTAKA}

Aini, N., Prihananto, V. dan Wijonarko, G. 2014. Karakteristik Kurva Isotherm Sorpsi Air Tepung Jagung Instan. Agritech 34(1): 50-55.

Alfiah, M. N., Hartini, S. dan Cahyanti, M. N. 2017. Permodelan Matematika dan Sifat Termodinamika Isoterm Sorpsi Air Tepung Singkong Terfermentasi Angkak. Jurnal Penelitian Kimia 13(1): 29-40.

Alvionita, V., Angkasa, D. dan Wijaya, H. 2017. Pembuatan Cookies Bebas Gluten Berbahan Tepung Mocaf dan Tepung Beras Pecah Kulit dengan Tambahan Sari Kurma. Jurnal Pangan dan Gizi 7(2): 72-81.

AOAC.1995. Official Methods of Analysis of The Association of Official Analytical Chemist, 14 ed. AOAC Inc. Airilington.

Assalam, S. et al. 2019. Pengaruh Ketebalan Irisan Chips Singkong dan Lama Fermentasi terhadap Sifat Fisiko Kimia Tepung Mocaf (Modified Cassava Flour). 3(1): 31-39.

Standar Nasional Indonesia Nomor 2973 Tahun 2011. Biskuit. Badan Standardisasi Nasional. Jakarta.

Standar Nasional Indonesia Nomor 7251 Tahun 2012. Mikrobiologi Bahan Pangan dan Pakan - Metode Horizontal untuk Deteksi dan Enumerasi Escherichia coli Terduga - Teknik Angka Paling Mungkin ( APM ). Badan Standardisasi Nasional.Jakarta.

International Standard Organization (ISO) Nomor 6579 Tahun 2002. Microbiology of Food and Animal Feeding Stuffs - Horizontal Method for The Detection of Salmonella spp. Fourth edition. International Standard Organization. Switzerland.

Kristanti, D., Setiaboma, W. dan Herminiati, A. 2020. Karakteristik Fisikokimia dan Organoleptik Cookies Mocaf dengan Penambahan Tepung Tempe. JurnalBiopropal Industri 11(1): 1-8. doi: http://dx.doi.org/10.36974/jbi.v11i1.5354.

Kusnandar, F., Adawiyah, D. R. dan Fitria, M. 2010. Pendugaan Umur Simpan Produk Biskuit dengan Metode Akselerasi Berdasarkan Pendekatan Kadar Air Kritis. Jurnal Teknologi dan Industri Pangan XXI(2): 1-6.

Mulyani, T., Djajati, S. dan Rahayu, L. D. 2015. Pembuatan Cookies Bekatul (Kajian Proposal Tepung Bekatul dan Tepung Mocaf) dengan Penambahan Margarine. Jurnal Reka Pangan 9(2): 1-8.

Ningtyas, N. S., Maryanto dan Windrati, W. S. 2012. Karakteristik Cookies Terigu yang Disubstitusi Campuran Tepung Kecambah Jagung (Zea mays) dan Tepung Gembolo (Dioscorea bulbifera L). Berkala IImu PertanianX: 1-6.

Öksüz, T. dan Karakaş, B. 2016. Sensory and textural evaluation of gluten-free biscuits containing buckwheat flour.Cogent Food \& Agriculture: 1-7. doi: 10.1080/23311932.2016.1178693.

Pertiwi, C. dan Ginting, S. 2017. Pendugaan Umur Simpan Cookies Nenas Dengan Metode Akselerasi Berdasarkan Pendekatan Kadar Air Kritis. Jurnal Rekayasa Pangan dan Pertanian. 5(1): 51-65.

Pratiwi, L. D. 2017. Pendugaan Umur Simpan Cookies Sumber Protein dan Energi dari Tepung Campuran Berbasis Mocaf dengan Variasi Kemasan. Skripsi. Program Studi Ilmu dan Teknologi Pangan Universitas Negeri Sebelas Maret Surakarta. Surakarta.

Pusat Data dan Sistem Informasi, P. 2015. Statistik Konsumsi Pangan Tahun 2015. Jakarta.

Soekarto, S. T. dan Hubeis, M. 1992. Metodologi Penelitian Organoleptik. Pusat Antar Universitas Pangan dan Gizi Institut Pertanian Bogor. Bogor.

Wijaya, I. M. A. S., Suter, I. K. dan Yusa, N. M. 2014. Karakteristik IsotermIs Sorpsi Air dan Umur Simpan Ledok Instan. Agritech 34(1): 29-35. 